УДК 811.161 .1

Р. П. Тимошук

\title{
ПРО ПОЛІСЕМІЮ В ПОЛЬСЬКІЙ ЛІНГВІСТИЧНІЙ ТЕРМІНОСИСТЕМІ
}

Тимошук Р. П. Про полісемію у польській лінгвістичній терміносистемі.

У статті проаналізовано явище полісемії у польській лінгвістичній терміносистемі, з'ясовано причини іï виникнення, виявлено основні типи багатозначності польських лінгвістичних терміноодиниць, визначено специфіку семантичної структури багатозначних лінгвістичних термінів у польських тлумачних та термінологічних словниках.

Ключові слова: полісемія, лінгвістична терміносистема, тлумачні та термінологічні словники.

Тимошук Р. П. О полисемии в польской лингвистической терминосистеме.

В статье проанализировано явление полисемии в польской лингвистической терминосистеме, определены причины ее возникновения, указаны основные типы многозначности лингвистических терминов, раскрыта специфика семантической структуры многозначных терминов лингвистики в польских толковых и терминологических словарях.

Ключевые слова: полисемия, лингвистическая терминосистема, толковые и терминологические словари.

Tymoshuk R. P. Polysemy in Polish linguistic terminology.

The article deals with the polysemy in Polish linguistic terminology, analyses the reasons of appearing polysemy in Polish linguistic terms, and their major types are defined. The specificity of semantic structure of polysemantic linguistic terms in Polish explanatory and terminological dictionaries is determined.

Key words: polysemy, linguistic terminology, explanatory and terminological dictionaries.

У сучасній славістиці однією з важливих проблем, яка потребує вивчень на етапі формування і функціонування назв галузевих понять, $\epsilon$ полісемія в термінологічних системах. Тому з'ясування закономірностей творення терміноодиниць, дослідження особливостей їх структури i семантики, взаємозв'язку із загальновживаною лексикою мають велике значення для термінознавства. Питання семантичної організації термінологічної лексики на рівні парадигматики неодноразово порушувались у працях українських та російських лінгвістів Б. М. Головіна [3], В. П. Даниленко [4], А. В. Крижанівської [5], I. С. Куликової [6], Д. С. Лотте [7], Т. І. Панько [9], Л. В. Рогач [11], 
Л. О. Симоненко [12] та інших учених. У польській лінгвістиці термінологічна полісемія розглядалася у працях С. Гайди [17], М. Бонка [14], Е. Гродзінського [18].

Дослідники галузевих терміносистем серед основних характеристик терміна, на відміну від загальновживаного слова, відзначають його моносемічність, тобто спеціальне слово мусить мати обмежений, чітко фіксований зміст, зрозумілий кожному поза контекстом [1, с. $158 ; 20$, с. 11 ; 7, с. 21]. Однак більшість польських та східнослов'янських науковців схиляються до думки, що однозначність - це лише тенденція термінологічних найменувань, однозначність термінів $є$ лише однією 3 вимог, які ставляться до нього $[14$, с. $19 ; 17$, с. $70-72 ; 4$, с. $65 ; 12$, с. $26-27$; 5, с. 103]. Якщо М. Бонк та В. П. Даниленко визначають полісемію в галузевих терміносистемах звичайним та закономірним явищем, адже терміни - це насамперед слова природної мови, і тому їм природно притаманні семантичні явища загальнолітературної лексики $[14$, с. 19 ; 4,c. 65], то С. Гайда вважає, що мова науки зберігає свій поліморфізм (багатозначність), диспонуючи природними, штучними, а також системними та контекстними засобами, що це явище одночасно обмежують або усувають залежно від потреб та мовної кваліфікації автора $[17$, с. 71$]$. В основі полісемії спеціальної лексики - зазначає вчений, лежить відношення слова до об'єктивної дійсності, а також його узагальнювальна природа.

Серед українських термінологів проблему полісемії досліджувала Л. О. Симоненко, яка вважає основою розвитку термінологічної багатозначності зміни структури мовного знака, який набуває нового змісту на основі схожості (метафора), часової і просторової суміжності (метонімія, синекдоха) з іншими поняттями. На думку дослідниці, у термінології, як і в літературній мові, не можна надовго зберегти однозначність, тому що людські знання про навколишній світ весь час поповнюються, у процесі пізнання виникають нові поняття, які потребують словесного вираження, тобто вони відбиваються в мові, у тому числі і в полісемії слова [12, с. 27].

У науковій літературі $є$ також спроби пояснити розвиток полісемії в термінах «міжкатегорійністю» та можливістю інтерпретувати, описувати об'єкт пізнання з різних позицій предметного і логічного знання, а також процесом термінологізації загальновживаних слів і детермінологізації термінів [2, с. 120]. Серед причин появи багатозначності в термінологічній лексиці виділяють: 1) присвоєння терміну значення, яке має спільні ознаки зі значенням терміна, що виражає інше поняття (ідеться про так звану категорійну багатозначність); 2) диференціація наукових понять і розхитування значення однозначного терміна у процесі його використання та подальшого доосмислення позначуваного ним поняття; 3) недостатня 
вивченість характеру окремих понять, що заважає дати їм чітке визначення $[11$, c. 23].

У галузевих терміносистемах багатозначність послідовно відбиває одну 3 важливих властивостей лексико-семантичної системи мови тенденцію до асиметричного дуалізму мовного знака, або до нерегламентованості співвідношення плану вираження і плану змісту, що є виявом мови до іiі економної систематизації, позначення нескінченного світу відносно обмеженою кількістю матеріальних мовних оболонок $[10$, с. $125 ; 13$, с. 524]. Ми розглядаємо полісемію як наявність в одного і того самого слова кількох пов'язаних між собою значень, що виникають у результаті видозміни і розвитку первинного значення цього слова. До цього основного стрижневого значення тяжіють усі переносні вторинні конотації, хоч міра їх близькості є неоднаковою.

У багатозначному лексико-семантичному просторі лінгвістичної терміносистеми польської мови виділяємо такі типи полісемії:

1) Зовнішньосистемна полісемія (зумовлена семантичною трансформацією багатозначного слова, коли одне 3 його значень поступово спеціалізується в назву певного наукового чи іншого подібного йому поняття 3 властивими йому семантичними й функціональними ознаками [1, с. 37]). Так, наприклад, шляхом звуження значення утворився польський лінгвістичний термін argument. Загальномовне значення терміноодинці - «fakt lub przekonanie stuzace do uzasadnienia jakichś racji lub decyzji» [USJP, t. 1, s. 48] - у термінологічному контексті набуває необхідної конкретизації: «subsumpcja podmiotu, dopetnienia $i$ uzupetnienia...» [EJO, s. 57]. Іменник aspekt ("punkt widzenia, z którego się coś rozpatruje; widok, perspektywa, wyglą, ujęcie, postać, przejaw, strona czegoś») шляхом семаничної спеціалізації позначає граматичну категорію дієслова в морфології: «kategoria gramatyczna czasownika wyrazajaca jego niedokonaność lub dokonaność» [USJP, t. 1, s. 72].

Термінологізація загальновживаних слів відбувається також шляхом переосмислення семантики мовних одиниць на основі подібності позначуваних реалій. Наприклад, іменник symptom в аналізованих тлумачних лексиконах подається в загальновживаному значенні: «oznaka czegoś, zwykle jakiegoś ujemnego zjawiska, często choroby; objaw, przejaw» [SJPSz, t. 3, s. 382], [USJP, t. 3, s. 1072]. Польські галузеві словники фіксують таке лінгвістичне значення терміноодиниці: «znak naturalny, przyporzadkowany danemu przedmiotowi na zasadzie przyczynowej $i$ pozwalajacy wnioskować o wystapieniu tego przedmiotu» [EJO, s. 578]. Подібним шляхом виникли у польській мові терміни gniazdo, rdzeń, składnik, wyspa тощо.

2) Внутрішньосистемна полісемія. Семантичною основою даного типу полісемії $є$ диференціація наукових понять і розхитування значення однозначного терміна в межах лінгвістичної терміносистеми $[11$, с. 27]. 
Наприклад, лінгвістичний термні wyraz 3 позиції фонетики-фонології означає «ciag fonemów zawartych między dwiema potencjalnymi pauzami z jednq sylaba...», в орфографії тлумачиться як «jednostka tekstu pisanego będaca ciagiem liter danego alfabetu ograniczonym dwoma odstępami lub odstępem i znakiem interpunkcyjnym», а з позиції граматики - «elementarna jednostka składni funkcjonalnej zdolna do wchodzenia w zwiazki syntaktyczne $z$ innymi wyrazami gramatycznymi» [EJO, s. 646]. Найчастіше внутрішньосистемна полісемія розвивається внаслідок метонімічного перенесення, в основі якого лежить зв'язок за суміжністю: дія - суб'єкт дії, дія - наслідок дії, ціле - частина цілого, розділ науки - назва об'єкта ії вивчення тощо [8, с. 80]. Наприклад, лінгвістичний термін nazalizacja в польській мовознавчій науці позначає властивість звуків: «nosowa artykulacja dodatkowa głoski», а також - фонетичний процес: "proces asymilacji fonetycznej polegajacy na pojawieniu się rezonansu nosowego $w$ głosce pod wplywem sasiedniej głoski nosowej» [EJO, s. 388]; термін etymologia вказує на походження слова: "pochodzenie wyrazu; źródtostów», а також тлумачиться як мовознавча дисципліна, що вивчає походження слів: «dyscyplina językoznawcza zajmujaca się badaniem pochodzenia wyrazów $i$ ich pierwotnych znaczeńn» [USJP, t. 1, s. 575]; одне 3 формул тлумачення полісемічного терміна słownictwo позначає конкретніше, вужче поняття і називає «wyrazy $i$ terminy dotyczace jakiejś specjalności, jakiegoś środowiska lub jakiegoś regionu», а у ширшому значенні вживається як «ogót wyrazów wchodzacych w skład jakiegoś języka, zasób wyrazów danego języka» [USJP, t. 3, s. 875].

У межах цього типу виділяємо категорійну та концептуальну (авторську) полісемію. Якщо перша виражає відношення «об'єкт вивчення - розділ науки» (наприклад, fleksja «odmiana wyrazów, zespót form stużacych do oznaczania stosunków między wyrazami w zdaniu», а також «dziat gramatyki zajmujacy się opisem tych form wyrazowych» [USJP, t. 1, s. 797]), то друга - пов'язана з відмінностями у науковій інтерпретації одного й того мовного явища. Авторську полісемію добре репрезентують лінгвістичні енциклопедії та термінологічні словники польської мови. Наприклад, Празька структуралістична школа термін fonem визначає як "zespót przystugujących mu fonologicznych cech dystynktywnych, traktowanych jako atrybuty fonemu - elementarnej jednostki struktury fonologicznej języka»; y теорії дистинктивних ознак Р. Якобсона даний термін означає «zespót wspótwystępujacych prostych jednostek fonologicznych cech dystynktywnych»; сучасне розуміння даної терміноодиниці як «funkcjonalnej, relacyjnej jednostki planu wyrażenia o funkcji dystynktywnej» запроваджене до польського мовознавства М. Крушевським та Я. Бодуеном де Куртене [EJO, s. 156]. Нового семантичного наповнення набувають - залежно від авторської позиції - лінгвістичні терміни: zdanie, znak, metajęzyk, makrolingwistyka, fraza, tekst тощо. 
3) Міжсистемна полісемія (виявляється в одночасному вживанні термінів на позначення галузевих понять в інших наукових дисциплінах: біології, фізиці, юриспруденції, медицині, філософії, психології, музиці, логіці, інформатиці тощо). Наприклад, терміноодиниця filtr у технічній науці тлумачиться як «przegroda lub urzadzenie stużace do oddzielania ciat stałych od cieczy lub gazów, zatrzymujace ciała stałe, a przepuszczajace płyny $i$ gazy», в інформатиці означає «rodzaj programu dokonujacego selekcji lub prostego przekształcenia danych wejściowych» [USJP, t. 1, s. 751], a y трансформаційно-генеративній граматиці - «ograniczenie naktadane na rzadek wygenerowany przez reguty gramatyczne, które określaja go jako niepoprawny (niegramatyczny)» [EJO, s. 154]. Термін elipsa в польському мовознавстві та літературознавстві інтерпретується як «орuszczenie $w$ zdaniu wyrazu lub wyrazów, domyślnych w szerszym kontekście; wyrzutnia», в геометрії позначає «jeden z przekrojów stożka, krzywa plaska zamknięta, w której suma odlegtości każdego punktu od danych dwóch punktów jest wielkościa stała» [SJPSz, t. 1, s. 538]. Лексична одиниця formant вживається у значенні «element, za pomoca którego dany wyraz zostal utworzony od swej podstawy stowotwórczej», однак у фізиці цей термін тлумачиться як «uwydatniona grupa składowych widma dźwięków» [USJP, t. 1, s. 842].

Багатозначність у галузевих терміносистемах пояснюється схожістю процесів та явищ у різних сферах діяльності людини. Ознака уподібнення проявляється в цих терміносистемах з різним ступенем інтенсивності і стосується різних об'єктів. Якщо в ідеалі термін у межах однієї терміносфери повинен мати лише одне точно окреслене значення - бути однозначним, то полісемія термінів на рівні кількох субмов - явище не тільки неуникненне, а й поширене, оскільки спеціальне слово, змінюючи своє значення, відображає різні аспекти об'єктивної дійсності, описує різні мовні змісти [18, с. 16].

Аналіз семантичної структури польських багатозначних мовознавчих терміноодиниць показав, що формули тлумачення у загальномовних словниках польської мови часто не збігаються 3 їх кваліфікацією у лінгвістичних термінологічних словниках та мовознавчих енциклопедіях, що пояснюється різним призначенням лексикографічних праць. Якщо тлумачні словники описують спеціальну лексику як частину лексикосемантичної системи загальнолітературної мови і включають як правило фрагменти термінологічних систем, то завдання галузевих словників та енциклопедій - максимально повне представлення системи наукових понять конкретної галузі. Так, реєстрові одиниці redukcja та podstawa słowotwórcza y «Słowniku terminologii językoznawczej та Encyklopedii językoznawstwa ogólnego» конкретизуються спеціалізованими, полісемічними дефініціями: redukcja 1) «osłabienie wymowy lub catkowity zanik jakiegoś dźwięku czy potaczenia dźwiękowego»; 2) «jeden z rodzajów transformacji elementarnych, polegający na ściagnięciu elementów $w$ jeden: $x+y \rightarrow z »$ 
[EJO, s. 482-483]; 1) «zanik pewnego elementu (fonemu lub grupy fonemów) w wyrazie lub formie»; 2) «jeden z rodzajów elementarnych transformacji» [STJ, s. 479]; podstawa slowotwórcza 1) "wyraz podstawowy w stosunku do derywatu, wyrazu fundowanego»; 2) «czesść wyrazu fundowanego» [EJO, s. 443]; тоді як у польських тлумачних словниках значення термінів $є$ більш узагальненими, зрозумілими для широкого загалу людей: redukcja «osłabienie artykulacji glosek, a także często ich zanik w wyrazie» [USJP, t. 3, s. 455], [SJPD, t. 7, s. 867]; podstawa slowotwórcza "wyraz podstawowy, którego temat zostaje użyty do utworzenia nowej jednostki wyrazowej» [SJPSz, t. 2, s. 749]. Схожим чином представлено формули тлумачення лінгвістичного терміна fonacja в польських тлумачних та галузевих словниках: «proces produkowania dźwięków mowy za pomoca ruchów artykulacyjnych narzadów mowy w trakcie konkretnego aktu mowy» [STJ, s. 172], 1) «(quasi-)periodyczny ruch drgający wiązadeł głosowych, będący źródtem dźwięku»; 2) «wszelka aktywność krtani $w$ procesie wytwarzania mowy, współdecydujaca o indywidualnym zabarwieniu głosu» [EJO, s.155], «wydawanie głosu przez człowieka, wymawianie dźwięków mowy» [SJPD, t. 2, s. 925], [SJPSz, t. 1, s. 601], [USJP, t. 1, s. 820].

Інша причина розбіжності словникових дефініцій - тенденція до розширення семантичного обсягу та ускладнення значеннєвої структури аналізованих термінологічних слів внаслідок розвитку лінгвістичної науки, виникнення нових напрямків i концепцій, що зумовлено переглядом поглядів мовознавців на об'єкти вивчення мовних явищ. Наприклад, термін emfaza в сучасному польському мовознавстві інтерпретується як «sposób ukształtowania wypowiedzi lirycznej lub oratorskiej silnie nacechowanej ekspresywnie», а також як «nacisk, jaki się ktadzie na któryś ze składników zdania» [EJO, s. 143-144]. «Słownik terminologii językoznawczej» 3. Голомба (1968p.) дану терміноодиницю подає тільки у першому значенні: «zjawisko stylistyczne polegajace na wzmożeniu ekspresywności wypowiedzenia przez odpowiednia postać morfologiczna, intonację, akcent lub specjalny szyk jego członów» [STJ, s. 156]. Іменник substytucja у словнику лінгвістичних термінів та мовознавчих енциклопедіях польської мови тлумачиться переважно у двох значеннях: 1) «zjawisko zastępowania powszechnego $w$ danym języku dźwięku $w$ mowie niektórych osób lub grup społecznych bądź terytorialnych przez dźwięk inny, mniej rozpowszechniony»; 2) «operacja zastapienia $w$ wyrażeniu języka jakiejś jego części przez inny element o tej samej wartości gramatycznej» [EJO, s. 572], [STJ, s. 543], [EWJP, s. 338-339]. Однак, аналіз пізніших лексикографічних видань вказує на розширення семантичної структури даної терміноодиниці у польській лінгвістиці: «w glossematyce substytucja stuży jako test do ustalania wariantów fakultatywnych»; «w gramatyce transformacyjno-generatywnej - typ reguty» [EJO, s. 572]. 
Іноді відмінності в лексикографічному представленні семантики багатозначних польських мовознавчих термінів пов'язані із концептуальною складністю визначення певних понять лінгвістики. Наприклад, термін konotacja в 11-ти томному тлумачному словнику В. Дорошевського кваліфікується як «współoznaczanie, oznaczanie zespołu cech wtórnie kojarzacych się ze znaczeniem podstawowym danego wyrazu» [SJPD, t. 3, s. 931], y «Słowniku języka polskiego» М. Шимчака ремарковане мовознавчою позначкою тільки одне із значень терміноодиниці: «роśrednie wskazywanie przez wyraz na konieczność występowania $w$ tekście wyrazu należącego do określonej kategorii językowej» [SJPSz, t. 1, s. 992]; формули тлумачення "реwne klasy wyrazów nie tylko oznaczajace bezpośrednio dane zjawisko, ale równocześnie pośrednio współoznaczające inne...» i «jedne formy gramatyczne konotujace inne formy» [STJ, s. 296] фіксує Stownik terminologii językoznawczej. У сучасних лексикографічних джерелах термін konotacja подається щонайменше у трьох значеннях, що вказує на звуження значення терміна, а також на відсутність концептуальної єдності у лінгвістичній інтерпретації даного термінопоняття: 1) «wyróżniona cecha (treść) charakterystyczna...; zespół cech, przystugujących wszystkim desygnatom danej nazwy»; 2) "oznaczanie przez określone klasy wyrazów z jednej strony bezpośrednio pewnych cech, ale z drugiej także współoznaczanie rzeczy związanych z tamtymi i tym samym otwieranie przez nie w tekście miejsc dla innych klas wyrażeń»; 3) «znaczenie taczne formy $i$ treści elementów językowych» [EJO, s. 310-311], [USJP, t. 2, s. 121].

Дослідження виявило нечисленну групу багатозначних лінгвістичних терміноодиниць, лексичні значення яких подаються в деяких тлумачних словниках як омонімічні. Лексикографічна інтерпретація багатозначначних лексем пов’язана 3 проблемою встановлення, чи дане явище $\epsilon$ результатом семантичного розвитку одного зі значень спеціального слова, чи його джерелом $\epsilon$ історичні процеси, яким підлягають генетично та значеннєво різні реєстрові одиниці. Так, лексична одиниця przypadek y тлумачних словниках M. Шимчака та В. Дорошевського представлена сіткою полісемічних значень: 1. «zdarzenie, zjawisko, których się nie da przewidzieć na podstawie znanych praw naukowych i doświadczenia; zdarzenie niespodziewane, zrzadzenie losu, zbieg okoliczności, traf»; 2. «jedna z postaci choroby spośród wielu podobnych; pojedyncza postać choroby»; 3. "forma gramatyczna imienia wyrazajaca stosunek syntaktyczny danego imienia do innych wyrazów w zdaniu» [SJPSz, t. 2, s. 1050], [SJPD, t. 7, s. 586], однак в Uniwersalnym słowniku języka polskiego C. Дубіша дане слово розкривається омонімічними значеннями: I «zdarzenie, zjawisko, których nie da się przewidzieć, zdarzenie niespodziewane, zrzadzenie losu, zbieg okoliczności; traf»; II «kategoria gramatyczna określająca składniowa funkcję rzeczownika, przymiotnika, zaimków oraz liczebników i imiesłowów odmiennych» [USJP, t. 3, s. 235]. Ha 
наш погляд, даний приклад свідчить про затирання та втрату семантичних зв'язків між лексичними значеннями даної терміноодиниці, внаслідок чого відбулось усамостійнення загальновживаного та термінологічного значень реєстрової одиниці. Аналогічно в аналізованих загальномовних лексиконах інтерпретуються значення таких лексичних одиниць як celownik, homofonia, homofoniczny. Вважаємо, що такі лінгвістичні терміни доцільно подавати в польських словниках як омоніми.

Отже, у лінгвістичній терміносистемі польської мови виділяються зовнішньосистемний, внутрішньосистемний та міжсистемний типи полісемії, які характеризуються неоднозначністю наукових понять i співвідносних із ними термінів. Специфіка подання семантичної структури польських лінгвістичних термінів у різних типах словників пояснюється як різними вимогами до укладання реєстру таких лексикографічних праць, так і способами узагальнення семантичних характеристик лінгвістичної термінології у слов’янській лексикографії.

\begin{tabular}{|c|c|}
\hline \multicolumn{2}{|r|}{ Умовні скорочення } \\
\hline SJPD & - Słownik języka polskiego / Red. W. Doroszewski. - Warszawa, 1958-1969. - T. 1-11. \\
\hline SJPSz & - Słownik języka polskiego / Red. M. Szymczak. - Warszawa, 1978-1981. - T. 1-3. \\
\hline USJP & - Uniwersalny słownik języka polskiego / Red. S. Dubisz. - Warszawa, 2003. - T. 1-4. \\
\hline ST & - Gołąb Z., Heinz A., Polański K. Słownik terminologii językoznawczej.- Warszawa, 1968. \\
\hline WIP & - Encyklopedia wiedzy o języku polskim / Red. S. Urbańczyk. - Wrocław, Warszawa, Kraków, \\
\hline & \\
\hline
\end{tabular}

\section{Література}

1. Білодід І. К. Сучасна українська літературна мова : Лексика і фразеологія / І. К. Білодід. - К : Наук. думка, 1973. $-438 \mathrm{c.}$

2. Глушко М. М. Полисемия и синонимия терминов / М. М. Глушко // Теория и практика английской научной речи. - М. : Московский университет, 1987. - Ч. 2. - С. 116-125.

3. Головин Б. Н. Лингвистические основы учения о терминах : Учеб. пособие для филол. спец. вузов / Б. Н. Головин, Р. Ю. Кобрин. - М. : Высш. шк., 1987. - 104 с.

4. Даниленко В. П. Русская терминология : Опыт лингвистического описания / В. П. Даниленко. - М. : Наука, 1977. - 246 с.

5. Крижанівська А. В. Склад і структура термінологічної лексики української мови / А. В. Крижанівська. - К. : Наук. думка, 1984. - 194 с.

6. Куликова И. С. Введение в металингвистику (системный, лексикографический и коммуникативнопрагматический аспекты лингвистической терминологии) / И. С. Куликова, Д. В. Салмина. - СПб. : САГА, 2002. $-352 \mathrm{c}$.

7. Лотте Д. С. Основы построения научно-технической терминологии / $\quad$ Д. С. Лотте. - М. : Изд-во АН СССР. $-1961 .-156 \mathrm{c}$.

8. Малевич Л. Д. Термінологічна полісемія: онтологія явища, різновиди, шляхи впорядкування / Л. Д. Малевич // Українська термінологія і сучасність : зб. наук. праць. - К. : КНЕУ, 2007. - Вип. VII. С. $78-81$.

9. Панько Т. І. Українське термінознавство : [підручник] / Т. І. Панько, І. М. Кочан, Г. П. Мацюк. Львів : Світ, 1994. -216 с.

10. Підвойний В. М. Лінгвістична термінологія турецької мови : дис. ... канд. філол. наук : 10.02.13 / Підвойний Володимир Миколайович. - К., 2001. - 215 с.

11. Рогач Л. В. Семантична основа лінгвістичних термінів в українській та англійській мовах : дис. ... канд. філол. наук : 10.02.15 / Рогач Леся Валер'янівна. - Ужгород, 2000. - 191 с.

12. Симоненко Л. О. Формування української біологічної термінології / Л. О. Симоненко. - К. : Наук. думка, 1991. $-151 \mathrm{c.}$ 
13. Тараненко О. О. Полісемія // Українська мова : Енциклопедія / Редкол. : Русанівський В. М., Тараненко О. О., Зяблюк М. П. та ін. - [3-тє вид., зі змінами і доп.]. - К. : Вид-во «Укр. енцикл.» імені М. П. Бажана, 2007. - С. 524-525.

14. Bąk M. Powstanie i rozwój polskiej terminologii nauk ścisłych / M. Bąk. - Wrocław : Zakład Narodowy im. Ossolińskich, 1984. - $184 \mathrm{~s}$.

15. Encyklopedia językoznawstwa ogólnego / [red. K. Polański]. - Wrocław : Zakład Narodowy im. Ossolińskich, 2003. - $731 \mathrm{~s}$.

16. Encyklopedia wiedzy o języku polskim / Red. S. Urbańczyk. - Wrocław, Warszawa, Kraków, Gdańsk : Zakład Narodowy im. Ossolińskich, 1978. - 446 s.

17. Gajda S. Wprowadzenie do teorii terminu / S. Gajda. - Opole : WSP, 1990. - 145 s.

18. Grodziński E. Wieloznaczność terminów filozoficznych / E. Grodziński // Poradnik językowy. Warszawa, 1986. - №1. - S. 15-25.

19. Jadacka H. Z problemów opisu leksykograficznego haseł wieloznacznych / H. Jadacka // Poradnik językowy. - Warszawa, 1990. - №6. - S. 437-442.

20. Lukszyn J. Termin i system terminologiczny w świetle praktyki terminograficznej / J. Lukszyn // Języki specjalistyczne. Metajęzyk lingwistyki. - Warszawa, 2001. - S. 7-26

21. Słownik języka polskiego / [red. W. Doroszewski]. - T. 1-11. - Warszawa : PWN, 1958-1969.

22. Słownik języka polskiego / [red. M. Szymczak]. - T. I-III. - Warszawa : PWN, 1978-1981.

23. Słownik terminologii językoznawczej / Gołąb Z., Heinz A., Polański K. - Warszawa: PWN, 1968. -847 s.

24. Uniwersalny słownik języka polskiego / [red. S. Dubisz]. - T. 1-4. - Warszawa : PWN, 2003. 